\title{
Effect of Physical Training on the Adipose Tissue of Diet-induced Obesity Mice: Interaction Between Reactive Oxygen Species and Lipolysis
}

Authors

Affiliation
J. M. de Farias, K. F. Bom, C. B. Tromm, T. F. Luciano, S. O. Marques, T. Tuon, L. A. Silva, F. S. Lira, C. T. de Souza, R. A. Pinho

Laboratory of Exercise Biochemistry and Physiology, Postgraduate Program in Health Sciences, Health Sciences Unit, Universidade do Extremo Sul Catarinense, Criciúma, SC, Brazil

\section{Key words \\ - exercise training \\ - high-fat diet \\ - epididymal fat \\ - oxidative stress \\ - lipolysis}

received 07.05 .2012 accepted 06.08 .2012

\section{Bibliography}

DOI http://dx.doi.org/

$10.1055 / \mathrm{s}-0032-1323740$

Published online:

September 12, 2012

Horm Metab Res 2013;

45: 190-196

(c) Georg Thieme Verlag KG

Stuttgart · New York

ISSN 0018-5043

\section{Correspondence}

\section{R. A. Pinho, PhD}

Laboratory of Exercise Biochemistry and Physiology

Postgraduate Program in

Health Sciences

Health Sciences Unit

Universidade do Extremo Sul

Catarinense

88806-000 Criciúma, SC

Brazil

Tel.: + 55/48/34312773

Fax: $+55 / 48 / 34312773$

pinho@unesc.net

\section{Abstract \\ $\nabla$}

It is well known that high-fat diets (HFDs) induce obesity and result in an increase in oxidative stress in adipose tissue, which leads to an impairment of fat mobilization by a downregulation of the lipases, such as hormone-sensitive lipase (HSL) and adipose triglyceride lipase (ATGL). On the other hand, exercise training leads to a reduction in adipose tissue and an improvement of antioxidant status and the lipolytic pathway. Our aim was to examine the influence of exercise and moderate intensity training on oxidative stress parameters and the relationship between the proteins involved in the lipolysis of animals subjected to a high-fat fed diet. Twenty-four mice were used and divided into 4 groups $(\mathrm{n}=6)$ : standard diet (SD); standard diet plus exercise (SD+Ex); high-fat diet (HFD); and high-fat diet plus exercise $(\mathrm{HFD}+\mathrm{Ex})$. The animals received

\section{Introduction}

$\nabla$

Obesity is a public health problem that affects individuals of all social classes, gender, and age. Genetic predisposition, several environmental and behavioral factors are associated with the pathophysiology of obesity, and are recognized as risk factors for lifestyle-related diseases, such as cardiovascular disease and diabetes [1]. On the other hand, exercise training has been used as an important therapeutic resource for both the treatment and prevention of several diseases. It is now known that exercise training results in less body weight, adipose tissue depots via the regulation of lipases, and induces anti-inflammatory and antioxidant profiles [2-5].

Adipose tissue fat stores are mainly dependent on fatty acid (FA) supply, FA esterification to triglycerides (TG), and TG breakdown, or lipolysis. Both adipose triglyceride lipase (ATGL) and hor-
HFD for 90 days and submitted to a daily training protocol in swinging. The animals were euthanized $48 \mathrm{~h}$ after the last session of exercise. White adipose tissue epididymal fat was excised for the measurement of oxidative stress parameters and protein levels of lipolytic enzymes by Western blotting. The results show an increase in body weight after 90 days of HFD, and exercise training prevented great gain. In adipose tissue, lipid peroxidation and protein carbonylation increased after HFD and decreased significantly after exercise training. The protein level of CGI-58 was reduced, and FAS was increased in the HFD than in SD, whereas ATGL exhibited an increase $(p<0.05)$ in HFD than in SD. The exercise plays a significant role in reducing oxidative damage, along with the regulation of proteins that are involved in the lipolysis of animals exposed to HFD.

mone-sensitive lipase (HSL) have the capacity for TG degradation by cleaving the ester bond, governing the lipolysis pathway in adipose tissue [6]. Adipose tissue lipolysis has received much attention over the past 10 years because of its altered regulation in obesity.

Studies have suggested that obesity is associated with changes in gene expression in adipocytes with different metabolic pathways and in different organs and tissues, resulting in various metabolic actions and molecular signals [7], and is closely associated with the low-grade chronic inflammatory response [2]. These biochemical and molecular changes involve the participation of a number of molecules as transcription factors, inflammatory mediators, and the formation of reactive oxygen species (ROS).

ROS are chemically reactive molecules that are produced during normal metabolism of oxygen and play important roles in cell signaling and 
homeostasis. However, ROS levels can increase dramatically due to several stimuli, and this may result in significant damage to cell structures [8]. Several studies show the involvement of ROS in the pathophysiology of obesity [2,9-11] and suggest that excessive ROS formation results in oxidative stress and inflammation induces significant changes in the gene expression of adipocytes, lipid metabolism, and the content of adipocytes. More recently, Krawczyk et al. [12] have postulated the contribution of oxidative stress to the control lipolysis in the adipose tissue. However, this interaction was never examined in obese animals that were concomitantly submitted to physical training protocol. Here, we examined the molecular and biochemical mechanisms involved in obesity, investigated the oxidative stress parameters and proteins involved in lipolysis in adipose tissue, and explored the effects of exercise training as nonpharmacologic therapy.

\section{Materials and Methods}

$\nabla$

\section{Samples}

Twenty-four 2-month-old male Swiss mice from the colony maintained by the Universidadade do Extremo Sul Catarinense (UNESC), Criciúma, Santa Catarina, Brazil, were used in this study. The animals were randomized into 4 groups $(n=6)$ : standard diet (SD); standard diet plus exercise (SD + Ex); high-fat diet (HFD); and high-fat diet plus exercise (HFD+Ex). They were housed 4 per cage in an animal room under a 12-h light-dark cycle at $22 \pm 1{ }^{\circ} \mathrm{C}$ and received a chow diet and water ad libitum. The experiments were carried out after a one-week acclimation period. All procedures were conducted in accordance with regulation no. 11794/08 (DOU 196, Section 1, October 2008) and approved by the local ethics committee.

\section{Diet and exercise protocol}

Composition of the experimental diet was according to Noeman and colleagues [11]. The diet applied was purchased from Nuvital Nutrientes SA, Brazil ( $\bullet$ Table 1). All animals had free access to water and food for 90 days. Thirty days after having started the high-fat diet, the animals were submitted to a daily training protocol. The exercise groups performed a continuous swimming program 5 days/week for 8 weeks. The mice swam for two 30-min sessions separated by a 5 -min break. The untrained animals were placed in an empty swimming pool for the same amount of time as the exercise group for the entire duration of

Table 1 Composition of high-fat and standard diet.

\begin{tabular}{|lcccc} 
& \multicolumn{2}{c}{ Standard diet } & \multicolumn{2}{c}{ High-fat diet } \\
Ingredients & $\mathbf{g} \cdot \mathbf{k g}^{-1}$ & $\mathbf{k c a l} \cdot \mathbf{k g}^{-\mathbf{1}}$ & $\mathbf{g} \cdot \mathbf{k g}$ & $\mathbf{k c a l} \cdot \mathbf{k g}^{-\mathbf{1}}$ \\
\hline Cornstarch & 398 & 1590 & 116 & 462 \\
\hline Casein & 200 & 800 & 200 & 800 \\
Sucrose & 100 & 400 & 100 & 400 \\
\hline Dextrinated starch & 132 & 528 & 132 & 528 \\
\hline Lard & - & - & 312 & 2808 \\
\hline Soybean oil & 70 & 630 & 40 & 360 \\
\hline Cellulose & 50 & - & 50 & - \\
\hline Mineral mix & 35 & - & 35 & - \\
\hline Vitamin mix & 10 & - & 10 & - \\
\hline L-Cystine & 3 & - & 3 & - \\
\hline Choline & 2.5 & - & 2.5 & - \\
Total & 1000 & 3948 & 1000 & 5358
\end{tabular}

the 8 weeks. After 4 weeks, a tail weight ( $5 \%$ of body weight) was used to increase the intensity of training. Training was conducted in a $120 \times 60 \times 50 \mathrm{~cm}$ pool with $10 \times 15 \times 50 \mathrm{~cm}$ lanes and containing $37.5 \mathrm{~cm}^{3}$ water that was temperature controlled at $30-32^{\circ} \mathrm{C}$.

\section{Weight and exercise control}

Body weight was measured both before and immediately after the last training sessions using a precision semi-analytic balance (Gehaka model BK300, precision $0.01 \mathrm{~g}$ ). Training intensity was controlled by the blood lactate level. Before and immediately after the first, twentieth, and last training sessions, approximately $25 \mu$ blood samples were collected from the caudal vein of animals for lactate measurement using a lactometer (Accusport). Control animals were submitted to one training session only, for lactate measurement sampling. Body weight was measured during all experimental periods using a precision semianalytic balance (Gehaka model BK300, precision $0.01 \mathrm{~g}$ ).

\section{Euthanasia}

Forty-eight hours after the last exposure session, mice were killed by cervical dislocation, and adipose tissue of visceral regions (epididymal fat) was surgically excised. Next, an aliquot of these tissues was homogenized in a specific buffer and used for biochemical analyses and intracellular proteins by Western blotting. The remaining material was stored in a freezer at $-80^{\circ} \mathrm{C}$ for further analysis.

\section{Homogenization of sample for Western blotting}

The samples were homogenized in a buffer containing $1 \%$ Triton $\mathrm{X} 100$, Tris $100 \mathrm{mM}$ (pH 7.4), sodium pyrophosphate $100 \mathrm{mM}$, EDTA $100 \mathrm{mM}$, sodium vanadate $10 \mathrm{mM}$, PMSF $2 \mathrm{mM}$, and aprotinine $0.1 \mathrm{mg} / \mathrm{ml}$ at $4^{\circ} \mathrm{C}$. The homogenate was then centrifuged at $11000 \mathrm{rpm}$ for $40 \mathrm{~min}$. The supernatant was used to determine the concentration of protein, and later, total extract was determined in the same material, using a specific antibody.

\section{Western blotting}

Aliquots containing $250 \mu \mathrm{g}$ of protein (per sample) were applied on a $1.5 \mathrm{~mm}$ thick polyacrylamide gel. Electrophoresis was conducted in a minigel cell (Bio Rad, Mini-Protean) with an electrophoresis buffer that had been diluted earlier. SDS-PAGE was initially conducted at $25 \mathrm{~V}$ (on the stacking gel) and $120 \mathrm{~V}$ (until the end of the resolution gel). Next, proteins separated by SDSPAGE were transferred to a nitrocellulose membrane using an electrotransference minigel device (Bio Rad), and the running buffer solution was maintained at $120 \mathrm{~V}$ for $2 \mathrm{~h}$ under continuous refrigeration using ice. Nitrocellulose membranes containing run proteins were incubated in a blocking solution for $2 \mathrm{~h}$ at room temperature to reduce the nonspecific protein ligation. Then, the membranes were washed thrice (for 10 min each time) in wash buffer and incubated in specific antibodies [anti-superoxide dismutase (SOD), anti-catalase (CAT), anti-ATGL (adipose triglyceride lipase), anti-CGI-58 (comparative gene identification 58), and anti-FAS (fatty acid synthase antibodies)] under constant shaking overnight at $4^{\circ} \mathrm{C}$. Next, the membranes were washed again thrice (for 10 min each time) in wash buffer and incubated in secondary antibodies conjugated with peroxide for $2 \mathrm{~h}$ at room temperature. Excess secondary antibody was washed with wash buffer, and then, the membranes were incubated in enzyme substrate for $2 \mathrm{~min}$ and exposed to an X-ray film (Kodak XAR, Rochester, NY, USA) with an intensifier (Cronex Lightning 
Plus, DuPont, Wilmington, DE, USA) in a radiography cassette. Band intensity was determined by reading radiographies developed by optic densitometry using a scanner (HP 3400) and the Scion Image software (Scion Corporation).

\section{Antioxidant enzyme activities}

Superoxide dismutase (SOD) activity was determined according to the method described by Bannister and Calabrese [13]. The enzymatic activity estimation occurs by adrenaline autooxidation inhibition read at $480 \mathrm{~nm}$ in a spectrophotometer. Enzyme activity was expressed as $\mathrm{U} / \mathrm{mg}$ protein. To determine catalase (CAT) activity, the sample was sonicated in a $50 \mathrm{mM}$ phosphate buffer, and the resulting suspension was centrifuged at $3000 \mathrm{~g}$ for $10 \mathrm{~min}$. The supernatant was used for enzyme assay. CAT activity was measured using the rate of decrease in hydrogen peroxide absorbance at $240 \mathrm{~nm}$, determined according to the method described in [14]. Enzyme activity was expressed as $\mathrm{U} / \mathrm{mg}$ protein.

\section{Oxidative damage}

Thiobarbituric acid reactive species (TBARS) was measured as a marker of lipid peroxidation by spectrophotometry at $532 \mathrm{~nm}$. Results were expressed as nmol TBARS/mg protein [15], and the generation of carbonyl groups in the reaction with 2,4-dinitrophenylhydrazine was used as a marker of the oxidation of proteins. Carbonyl content was determined by spectrophotometry at $370 \mathrm{~nm}$ with a coefficient of 22000 molar $^{-1}$ and was expressed as nmol/mg protein [16].

\section{Protein content}

Protein content was assayed using bovine serum albumin as a standard. A folin phenol reagent (phosphomolybdic-phosphotungstic reagent) was added to bind the protein. The bound reagent was slowly reduced and changed from yellow to blue. Absorbance was read at $750 \mathrm{~nm}[17]$.

\section{Statistical analysis}

Data are expressed as mean and standard error of the mean and analyzed using a two-way analysis of variance (ANOVA) followed by Tukey's post hoc test in the Statistical Package for Social Sciences (SPSS 16.0). Significance level was defined as $\mathrm{p}<0.05$.

\section{Results}

$\nabla$

\section{Body weight and training control}

- Table 2 shows body weight after exposure to a high-fat diet and exercise training protocol. Body weight in the HFD showed increased 37\% ( $<<0.001)$, whereas HFD + Ex exhibited increased $15 \%(\mathrm{p}<0.05)$ when compared with SD. In addition, HFD + Ex exhibits a body weight of $19 \%$ minor ( $p<0.05$ ) in relation to HFD. Lactate level increased in both groups treated with a standard diet and a high-fat diet, in relation to basal values.

\section{Antioxidant enzymes}

- Fig. 1 shows that SOD activity and level changed after exercise training with regard to animals' exposure to HFD. The SOD level in adipose tissue showed an increase in HFD $(\mathrm{p}<0.05)$ compared to SD, whereas the HFD+Ex group showed an increase in SOD activity relative to $\mathrm{SD}, \mathrm{HFD}$, and $\mathrm{SD}+\mathrm{Ex}(\mathrm{p}<0.05)$. In relation to CAT ( $\bullet$ Fig. 2 ), the results showed an increase in activity in the HFD + Ex in relation to HFD ( $p<0.05)$, whereas the protein level of enzymes in adipose tissue was increased in the HFD+Ex group compared to SD, HFD, and SD + Ex ( $\mathrm{p}<0.05)$.

\section{Oxidative damage}

- Fig. 3 shows the values of TBARS and carbonyl protein. In the adipose tissue, the lipid peroxidation and protein oxidation were significantly increased in the HFD $(\mathrm{p}<0.01)$ compared to the SD group. In contrast, exercise training leads to a decrease in both parameters $(\mathrm{p}<0.01)$.

\begin{tabular}{|llllll|} 
Groups & Body weight $(\mathbf{m g})$ & \multicolumn{2}{l}{ Blood lactate $(\mathbf{n m o l} / \mathbf{l})$ Mean \pm SEM } & \\
& Mean \pm SEM & Basal & $\mathbf{1}^{\text {st }}$ session & $\mathbf{2 0}^{\text {th }}$ session & Last session \\
\hline SD & $40.43 \pm 1.08$ & & - & - & - \\
\hline HFD & $55.29 \pm 2.00^{*}$ & $2.13 \pm 0.19$ & - & - & - \\
\hline SD +Ex & $37.14 \pm 0.90$ & & $3.92 \pm 0.13^{*}$ & $4.27 \pm 0.25^{*}$ & $4.13 \pm 0.27^{*}$ \\
\hline HFD +Ex & $46.88 \pm 1.83^{* \$}$ & & $4.10 \pm 0.10^{*}$ & $4.60 \pm 0.20^{*}$ & $4.48 \pm 0.28^{*}$ \\
\hline
\end{tabular}

Blood lactate level (mmol/l) of mice exposed to physical training, a high-fat diet (HFD), and a standard diet (SD). Values are presented as mean \pm SEM, and $p<0.05$ was considered as the minimum significance between the groups

${ }^{*}$ Different from a standard diet (SD). ${ }^{\#}$ Different from a high-fat diet (HFD). ${ }^{\$}$ Different from a standard diet plus exercise (SD + Ex)

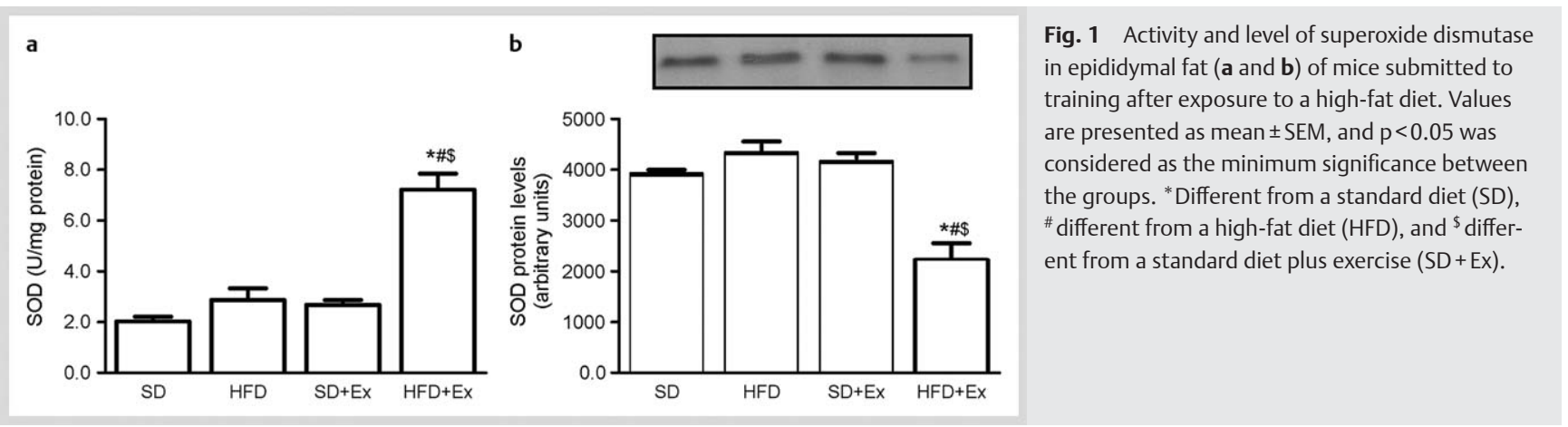

Table 2 Body weight and training control. 


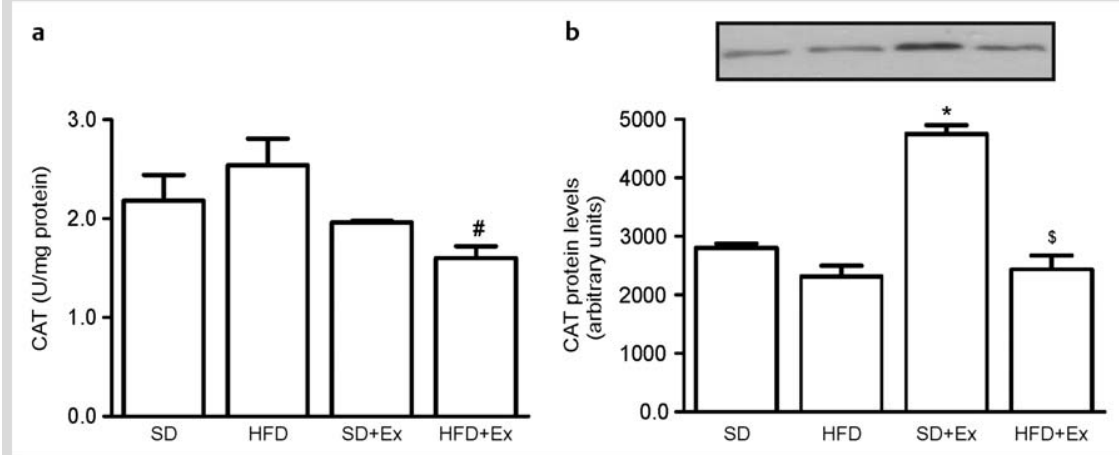

Fig. 2 Activity and level of catalase in epididymal fat ( $\mathbf{a}$ and $\mathbf{b}$ ) of mice submitted to training after exposure to a high-fat diet. Values are presented as mean \pm SEM, and $p<0.05$ was considered as the minimum significance between the groups. *Different from a standard diet (SD), "different from a high-fat diet (HFD), and ${ }^{\$}$ different from a standard diet plus exercise $(\mathrm{SD}+\mathrm{Ex})$.
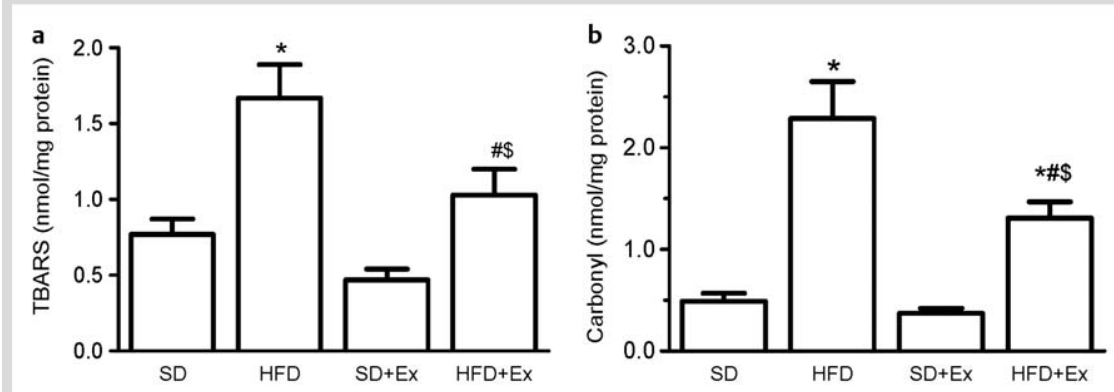

Fig. 3 TBARS level $\mathbf{a}$ and carbonyl content $\mathbf{b}$ in epididymal fat of mice submitted to training after exposure to a high-fat diet. Values are presented as mean \pm SEM, and $p<0.05$ was considered as the minimum significance between the groups. *Different from a standard diet (SD), "different from a high-fat diet (HFD), and ${ }^{\$}$ different from a standard diet plus exercise $(S D+E x)$.
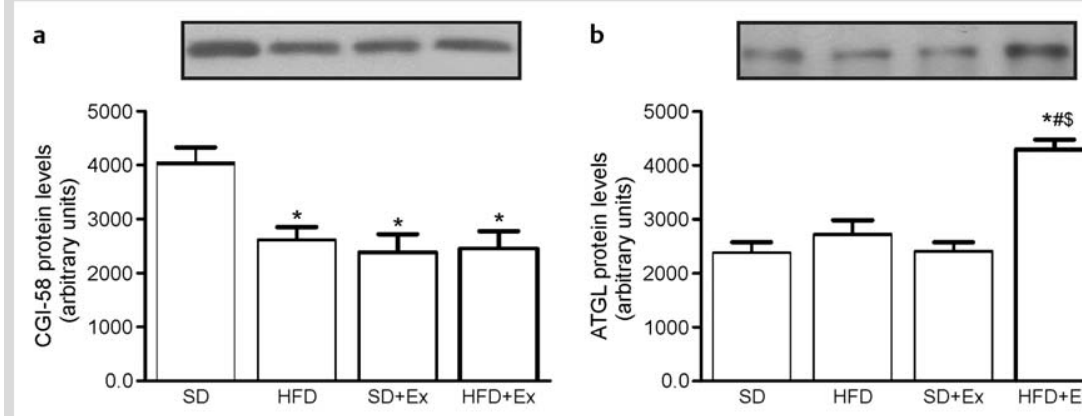

Fig. 4 Levels of adipose triglyceride lipase (ATGL), comparative gene identification 58 (CGI-58), and fatty acid synthase (FAS) in the epididymal fat of mice submitted to training after exposure to a

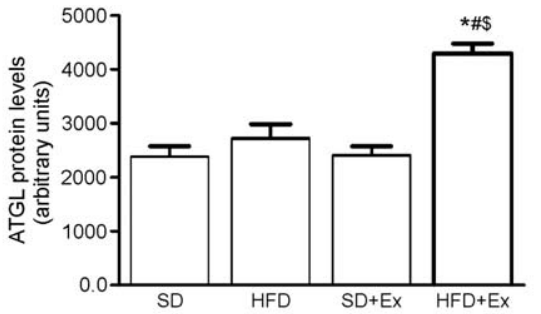
high-fat diet. Values are presented as mean \pm SEM, and $p<0.05$ was considered as the minimum significance between the groups. * Different from a standard diet (SD), "different from a high-fat diet (HFD), and ${ }^{5}$ different from a standard diet plus exercise $(S D+E x)$.

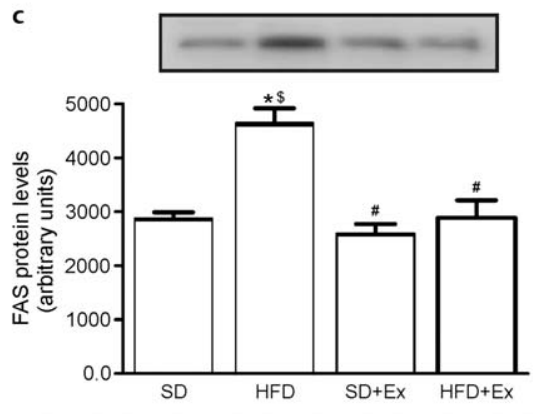

\section{Lipolytic and lipogenic proteins}

- Fig. 4 shows the data of ATGL, CGI-58, and FAS, respectively. ATGL protein levels were increased in the HFD $+E x(p<0.05)$ compared to all the groups. CGI-58 protein levels were reduced in all the groups $(\mathrm{p}<0.05)$ in relation to the SD groups. FAS protein levels increased in the HFD $(\mathrm{p}<0.05)$ relative to the SD and $\mathrm{HFD}+$ Ex groups, whereas they exhibited decreases in the SD+Ex and HFD + Ex $(p<0.05)$ than in the SD group.

\section{Discussion}

Our results indicate that obesity induces great alterations with regard to several biochemical and molecular parameters in adipose tissue, whereas physical training rebalances these alterations, improving antioxidant profile, and increasing ATGL protein level, which induces minor weight gain. Here, we have demonstrated that, at least in part, changes in oxidative stress are associated with the lipolysis process in adipose tissue in high-fat fed mice. 
Lactate content was used to monitor changes in the physical capacity of animals and to control the training intensity. Changes in muscle mass alter the energetic metabolism due to differences in oxidative and glycolytic capacities for adenosine triphosphate (ATP) turnover. Thus, this marker may be considered as an indicator of the intensity of physical effort during training. Our results show an increase in lactate content in all groups after training sessions (immediately after the first, the twentieth, and the last training session). This increase suggests that the protocol utilized reflects aerobic training and can result in an impact on oxidative metabolism.

Obesity is closely associated with ROS, and studies have shown that the unbalance between oxidant production and the antioxidant defense system is critically involved in the pathogenesis of obesity in the human $[9,10]$ and experimental model $[11,18]$. It has been reported that obesity may induce systemic oxidative stress, and oxidative stress is associated with the overproduction of proinflammatory adipokines [19]. In contrast, antioxidant defense markers are lower depending on the amount of body fat $[20,21]$. Our data corroborated with those found in the literature, which showed that adipose tissue in high-fat fed diet mice exhibits an increase in ROS concentrations [22].

The increase in obesity-associated ROS is probably due to the relationship between obesity and chronic inflammation, because adipocytes and preadipocytes have been identified as a source of proinflammatory cytokines, including TNF- $\alpha$, IL-1 $\beta$, and IL-6 $[23,24]$, and these cytokines serve as potent stimulators for the production of ROS by macrophages and monocytes [25]. In addition, it is observed that disruption in the lipolysis pathway leads to accumulated TAG in the adipose tissue, which favors an increase in this tissue and aggravates obesity.

Adipocyte triglyceride lipase (ATGL) and hormone-sensitive lipase (HSL) assume triglyceride hydrolase activities in the adipose tissue. Lipolysis, which is coordinated by lipases, occurs through catecholamine stimulation of $\beta$-adrenergic receptors and the subsequent activation of protein kinase A (PKA) [26]. In mice, the inhibition of HSL and ATGL has been shown to promote diet-induced obesity and its associated metabolic defects [27]. In humans, both HSL and ATGL protein levels are decreased in the adipose tissue from obese patients compared with that from lean individuals $[28,29]$.

Our data show that the FAS protein level is increased in the adipose tissue in high-fat-fed diet mice, which favors the synthesis of fatty acids, whereas there are no changes observed in the ATGL protein level. The limitation of the present study was that phosphorylation of the enzyme was not examined. Taken together, our data suggest that an increase in oxidative stress is accompanied by the disruption lipolysis process in the adipose tissue high-fat fed diet mice. On the other hand, exercise training has been associated with an improvement in the antioxidant defense system and a decrease in oxidative damage in the brain [30], lung [31], liver [32], muscle [33], kidney [34], heart [35], adipose tissue [2], and other tissues as well as the reduction in obesity [36,37].

In the present study, we demonstrated that exercise training prevents marked weight adipose tissue gain, oxidative damage, and recovery of the ATGL protein level in adipose tissue. These data suggest that the protector effects of exercise training have a link between reduced ROS and the lipolysis pathway. This interaction has been recently postulated by Krawczyk et al. [12], who demonstrated that ROS facilitates the translocation of HSL to the lipid droplet during lipolysis in human adipocytes.
Intracellular antioxidant enzymes play an important role in cellular antioxidant defenses. SOD and CAT are the 2 major scavenging enzymes that remove radicals in vivo, and a decrease in the activity of these enzymes can lead to an excess availability of superoxide anion and hydrogen peroxide, which, in turn, lead to the generation of hydroxyl radicals, resulting in the initiation and propagation of lipid peroxidation and protein modification [8]. The increase in the activity and content of SOD observed in this study probably results from the concomitant increase in the production of ROS (superoxide), and this does not necessarily mean that the cell is exposed to oxidative stress. The extent to which the benefits of moderate exercise (training) might be related to the upregulation of SOD (activity and content). The increase in the activity and content of antioxidant enzymes induced by exercise is the main reason for the reduction of oxidative damage that is also observed in this study. We observed that there was a different modulation of SOD and CAT in the adipose tissue in trained animals, when compared with untrained animals. The results suggest that SOD seems to be highly modulated by exercise training. The most striking finding was the remarkable increase in SOD activity and protein levels observed in trained rats without a proportional increase in CAT activity. SOD reduces the superoxide radical to hydrogen peroxide $\left(\mathrm{H}_{2} \mathrm{O}_{2}\right)$, which is the substrate of CAT. When the cell has increased levels of SOD without a proportional increase in peroxidases, cells face a peroxide overload challenge [8]. However, the reduction of CAT in adipose tissue may be due to the rapid consumption and exhaustion of the storage of this enzyme in fighting free radicals generated during the development of obesity [11], although the increase in activity was an expected result. This result may be one factor that is responsible for increased oxidative damage, and exercise training minimized these effects. The decrease in catalase can lead to redox imbalance and can accumulate peroxides, reacting with transitional metals, generating the hydroxyl radical, which is the most harmful radical. This may explain the observed increase in oxidative damage after HFD.

Exercise training was sufficiently able to prevent the increase in the levels of lipid peroxidation and protein oxidation. According to Petersen and Pedersen [3], exercise exerts an anti-inflammatory effect by inducing increased levels of IL-6. IL-6 not only induces an anti-inflammatory environment by inducing the production of IL-1ra and IL-10, but also inhibits TNF- $\alpha$ production [38-40]. In addition, exercise training appears to attenuate NADPH oxidase activity as result of elevated eNOS production and other factors [41]. In a recent study, Sakurai and colleagues [2] verified the effects of exercise training on oxidative stress in rats in the adipose tissue, especially focusing on inflammationrelated adipokines. The results showed a reduction in oxidative damage and an increase in SOD content induced by exercise training. In addition, the study also showed a decrease in the expression of NADPH oxidase, and the authors suggest that this reduction is associated with lower oxidative damage in exercised animals.

In relation to lipolysis, we also observed a great elevation in the protein expression of ATGL in HFD+Ex. The data corroborate with minor weight of adipose tissue gain in the exercised groups that, at least in part, show recovery of lipolysis process. Chapados et al. [42] have shown that physical training decreases in vitro stimulated lipolysis in a visceral but not in the retroperitoneal fat depot of high-fat fed rats. The authors showed that the elevation in stimulated lipolysis was reduced by training in high- 
fat-fed rats and might, at a first glance, simply reflect a reduction in fat mass in the adipose tissue.

In contrast to HSL, ATGL appears to reside on the lipid droplet surface independent of PKA activation [43]. Rather than its activation being controlled by phosphorylation and translocation, ATGL is activated at least 20-fold by interactions with CGI-58, a member of an esterase/lipase family of proteins [44]. Comparative Gene Identification-58 (CGI-58) is also known as $\alpha / \beta$ hydrolase domain-containing protein 5 (Abhd5). CGI-58 lacks lipase activity itself, but activates the lipase activity of ATGL likely via protein-protein interaction. Fluorescence resonance energy transfer studies support a model in which CGI-58 binds to perilipin in adipocytes under basal conditions but is released from perilipin on lipolytic stimulation [45]. We suggest that, despite reduced CGI-58 protein levels in the HFD, the interactions between CGI-58 and perilipin have been increased, but cannot affirm this situation. More studies are needed to confirm the suggestion.

In summary, the results of this study suggest that antioxidant enzymes play a significant role in the regulation of obesity, but are not sufficient to reduce the oxidative damage induced by exposure to HFD. However, since we did not determine antiinflammatory cytokines and NAPH oxidase, the exact role of physical training in the modulation of oxidative stress in animals exposed to HFD should be confirmed in future studies.

\section{Acknowledgements}

$\nabla$

This research was supported by CNPq/MCT (Brazil), CAPES/MEC (Brazil), FAPESC (Brazil), and UNESC (Brazil).

\section{Conflict of Interest \\ $\nabla$}

The authors have no conflict of interest.

\section{References}

1 Blakemore AIF, Froguel P. Is Obesity Our Genetic Legacy? J Clin Endocrinol Metab 2008; 93 (Suppl 1): S51-S56

2 Sakurai T, Izawa T, Kizaki T, Ogasawara JE, Shirato K, Imaizum IK, Takahashi $\mathrm{K}$, Ishida $\mathrm{H}$, Ohno $\mathrm{H}$. Exercise training decreases expression of inflammation-related adipokines through reduction of oxidative stress in rat while adipose tissue. Biochem Biophys Res Commun 2009; 379: 605-609

3 Petersen $A M$, Pedersen $B K$. The anti-inflammatory effect of exercise. 2005; J Appl Physiol 98: 1154-1162

4 Pinho R, Andrades ME, Oliveira MR, Pirola AC, Zago MS, Silveira PC, Dal-Pizzol F, Moreira JC. Imbalance in SOD/CAT activities in rat skeletal muscles submitted to treadmill training exercise. Cell Biol Int 2006; 30: 848-853

5 Lira FS, Rosa JC, Yamashita AS, Koyama CH, Batista MLJr, Seelaender M. Endurance training induces depot-specific changes in IL-10/TNF-alpha ratio in rat adipose tissue. Cytokine 2009; 45: 80-85

6 Bezaire V, Mairal A, Ribet C, Lefort C, Girousse A, Jocken J, Laurencikiene J, Anesia R, Rodriguez AM, Ryden M, Stenson BM, Dani C, Ailhaud $G$, Arner P, Langin D. Contribution of adipose triglyceride lipase and hormone-sensitive lipase to lipolysis in hMADS adipocytes. J Biol Chem 2009; 284: 18282-18291

7 Attie $A D$, Scherer PE. Adipocyte metabolism and obesity. J Lipid Res 2009; 50: S395-S399

8 Halliwell B, Gutteridge JMC. Free Radical in Biology Medicine. Oxford: University Press, 2007; 187-267

9 Furukawa S, Fujita T, Shimabukuro M, Iwaki M, Yamada Y, Nakajima $Y$, Nakayama $O$, Makishima M, Matsuda M, Shimomura I. Increased oxidative stress in obesity and its impact on metabolic syndrome. J Clin Invest 2004; 114: 1752-1761
10 Stefanović A, Kotur-Stevuljević J, Spasić S, Bogavac-Stanojević N, Bujisić $N$. The Influence of obesity on the oxidative stress status and the concentration of leptin in type 2 diabetes mellitus patients. Diabetes Res Clin Pract 2008; 79: 156-163

11 Noeman SA, Hamooda HE, Baalash AA. Biochemical study of oxidative stress markers in the liver, kidney and heart of high fat diet induced obesity in rats. Diabetol Metab Syndr 2011; 3: 17

12 Krawczyk SA, Haller JF, Ferrante T, Zoeller RA, Corkey BE. Reactive oxygen species facilitate translocation of hormone sensitive lipase to the lipid droplet during lipolysis in human differentiated adipocytes. PLoS One 2012; 7: e34904

13 Bannister JV, Calabrese L. Assay for SOD. Methods Biochem Anal 1987; 32: 279-312

14 Aebi H. Catalase in vitro. Methods Enzymol 1984; 105: 121-126

15 Draper HH, Hadley M. Malondialdehyde determination as index of lipid peroxidation. Methods Enzymol 1990; 186: 421-431

16 Levine RL, Garland D, Oliver CN, Amici A, Climent I, Lenz AG, Ahn BW, Shaltiel S, Stadtman ER. Determination of carbonyl content in oxidatively modified proteins. Methods Enzymol 1990; 186: 464-478

17 Lowry OH, Rosebrough NJ, Farr AL, Randall JR. Protein measurement with the Folin phenol reagent. J Biol Chem 1951; 193: 265-275

18 Carmiel-Haggai M, Cederbaum AI, Nieto N. A high-fat diet leads to the progression of non-alcoholic fatty liver disease in obese rats. FASEB J 2005; 19: 136-138

19 Esposito K, Giugliano G, Scuderi N, Giugliano D. Role of adipokines in the obesity-inflammation relationship: the effect of fat removal. Plast Reconstr Surg. 2006; 118: 1048-1057 discussion 1058-1059

20 Chrysohoou C, Panagiotakos DB, Pitsavos C, Skoumas J, Economou M, Papadimitriou L, Stefanadis C. The association between pre-hypertension status and oxidative stress markers related to atherosclerotic disease: the ATTICA study. Atherosclerosis 2007; 192: 169-176

21 Hartwich J, Góralska J, Siedlecka D, Gruca A, Trzos M, Dembinska-Kiec A. Effect of supplementation with vitamin $\mathrm{E}$ and $\mathrm{C}$ on plasma hsCRP level and cobalt-albumin binding score as markers of plasma oxidative stress in obesity. Genes Nutr 2007; 2: 151-154

22 Vincent HK, Taylor AG. Biomarkers and potential mechanisms of obesity-induced oxidant stress in humans. Int J Obes (Lond) 2006; 30: $400-418$

23 Oller do Nascimento CM, Ribeiro EB, Oyama LM. Metabolism and secretory function of white adipose tissue: effect of dietary fat. An Acad Bras Cienc 2009; 81: 453-466

24 Yamashita AS, Lira FS, Rosa JC, Paulino EC, Brum PC, Negrão CE, dos Santos RV, Batista ML Jr., do Nascimento CO, Oyama LM, Seelaender M. Depot-specific modulation of adipokine levels in rat adipose tissue by diet-induced obesity: the effect of aerobic training and energy restriction. Cytokine 2010; 52: 168-174

25 Morrow J. Is an oxidative stress a connection between obesity and atherosclerosis. Arterioscler Thromb Vasc Biol 2003; 23: 368-370

26 Marcelin G, Chua S Jr. Contributions of adipocyte lipid metabolism to body fat content and implications for the treatment of obesity. Curr Opin Pharmacol 2010; 10: 588-593

27 Haemmerle G, Zimmermann R, Zechner R. Letting lipids go: hormonesensitive lipase. Curr Opin Lipidol 2003; 14: 289-297

28 Langin D, Dicker A, Tavernier G, Hoffstedt J, Mairal A, Rydén M, Arner E, Sicard A, Jenkins CM, Viguerie N, van Harmelen V, Gross RW, Holm $C$, Arner P. Adipocyte lipases and defect of lipolysis in human obesity. Diabetes 2005; 54: 3190-3197

29 Watt MJ, Steinberg GR. Regulation and function of triacylglycerol lipases in cellular metabolism. Biochem J 2008; 414: 313-325

30 Tuon T, Valvassori SS, Lopes-Borges J, Fries GR, Silva LA, Kapczinski F, Quevedo J, Pinho RA. Effects of moderate exercise on cigarette smoke exposure-induced hippocampal oxidative stress values and neurological behaviors in mice. Neurosci Lett 2010; 475: 16-19

31 Menegali BT, Nesi RT, Souza PS, Silva LA, Silveira PC, Valença SS, Pinho $R A$. The effects of physical exercise on the cigarette smoke-induced pulmonary oxidative response. Pulm Pharmacol Ther 2009; 22: 567-573

32 Silva LA, Pinho CA, Rocha LG, Tuon T, Silveira PC, Pinho RA. Effect of different models of physical exercise on oxidative stress markers in mouse liver. Appl Physiol Nutr Metabol 2009; 34: 60-65

33 Silva LA, Pinho CA, Scarabelot KS, Fraga DB, Volpato AM, Boeck CR, De Souza CT, Streck EL, Pinho RA. Physical exercise increases mitochondrial function and reduces oxidative damage in skeletal muscle. Eur J App Physiol 2009; 105: 861-867

34 Coelho BL, Rocha LG, Scarabelot KS, Scheffer DL, Ronsani MM, Silveira PC, Silva LA, Souza CT, Pinho RA. Physical exercise prevents the exacerbation of oxidative stress parameters in chronic kidney disease. J Renal Nutr 2010; 20: 169-175 
35 Frederico MJ, Justo SL, Da Luz G, Da Silva S, Medeiros C, Barbosa VA, Silva LA, Boeck CR, De Pinho RA, De Souza CT. Exercise training provides cardioprotection via a reduction in reactive oxygen species in rats submitted to myocardial infarction induced by isoproterenol. Free Rad Res 2009; 43: 957-694

36 Gomez-Cabrera MC, Domenech E, Vina J. Moderate exercise is an antioxidant: upregulation of antioxidant genes by training. Free Rad Biol Med 2008; 44: 126-131

37 Buettner R, Schölmerich J, Bollheimer CL. High-fat Diets: Modeling the Metabolic Disorders of Human Obesity in Rodents. Obesity 2007; 15: 798-808

38 Pinho RA, Silva LA, Pinho CA, Scheffer DL, Souza CT, Benetti M, Carvalho $T$, Dal-Pizzol F. Oxidative stress and inflammatory parameters after an Ironman race. Clin J Sport Med 2010; 20: 306-311

39 Gleeson M, Bishop NC, Stensel DJ, Lindley MR, Mastana SS, Nimmo MA. The anti-inflammatory effects of exercise: mechanisms and implications for the prevention and treatment of disease. Nat Rev Immunol 2011; 11: 607-615

40 Pedersen BK, Febbraio MA. Muscles, exercise and obesity: skeletal muscle as a secretory organ. Nat Rev Endocrinol Apr 3 2012, doi:10.1038/ nrendo.2012.49. [Epub ahead of print]
41 Jenkins NT, Witkowski S, Spangenburg EE, Hagberg JM. Effects of acute and chronic endurance exercise on intracellular nitric oxide in putative endothelial progenitor cells: role of NAPDH oxidase. Am J Physiol Heart Circ Physiol 2009; 297: H1798-H1805

42 Chapados $N$, Collin P, Imbeault P, Corriveau P, Lavoie JM. Exercise training decreases in vitro stimulated lipolysis in a visceral (mesenteric) but not in the retroperitoneal fat depot of high-fat-fed rats. Br J Nutr 2008; 100: 518-525

43 Zimmermann R, Strauss JG, Haemmerle G, Schoiswohl G, Birner-Gruenberger R, Riederer $M$, Lass A, Neuberger G, Eisenhaber F, Hermetter A, Zechner $R$. Fat mobilization in adipose tissue is promoted by adipose triglyceride lipase. Science 2004; 306: 1383-1386

44 Lass A, Zimmermann R, Haemmerle G, Riederer M, Schoiswohl G, Schweiger M, Kienesberger P, Strauss JG, Gorkiewicz G, Zechner R. Adipose triglyceride lipase-mediated lipolysis of cellular fat stores is activated by CGI-58 and defective in Chanarin-Dorfman Syndrome. Cell Metab 2006; 3: 309-319

45 Granneman JG, Moore HP, Granneman RL, Greenberg AS, Obin MS, Zhu Z. Analysis of lipolytic protein trafficking and interactions in adipocytes. J Biol Chem 2007; 282: 5726-5735 